\title{
INTERCULTURAL DIFFERENCES IN BLACK SEA AREA PEOPLE
}

\author{
(C) Yulia P. Ten \\ Rostov branch of Russian customs academy \\ Rostov-on-Don, Russian Federation \\ science-almanac@mail.ru
}

The Russian Federation is one of the countries of the Black Sea region cultural zone. Since the ancient times, the territory of the South of Russia has been a zone of dialogue of different cultures, religions and civilizations. In the process of intercultural communication, representatives of different cultures have been aware of the degree of intercultural differences between them. The author justifies the thesis that communication between representatives with a similar cultural background has wider prospects for mutual understanding than communication between communicators with different cultural bases. The article analyzes the problem of growth and reduction of cultural differences between post-Soviet countries. In particular, the author points to the fact that the creation of the Eurasian Economic Union is a factor that promotes the effectiveness of intercultural communication between the member countries of this union.

Key words: culture, cultural differences, intercultural communication, symbols as a non-verbal means of intercultural communication, cultures of the Black Sea area, the Eurasian Economic Union.

\section{[Ю.П. Тен Межкультурные различия народов зоны Причерноморья]}

Российская Федерация является одной из стран культурной зоны стран Причерноморья. С древних времен территория Юга России - зона диалога разных культур, религий и цивилизаций. В процессе межкультурной коммуникации представители разных культур осознают степень межкультурных различий между ними. Автор обосновывает положение о том, что коммуникация между представителями со схожим культурным базисом (backgrounds) имеет более широкие перспективы для взаимопонимания, чем коммуникация между коммуникаторами с различными культурными основаниями. Анализируется проблема роста и снижения культурных различий между постсоветскими странами. В частности, автор указывает на то, что создание Евразийского экономического союза - фактор, способствующий росту эфффективности межкультурной коммуникации между странами-членами данного союза.

Ключевые слова: культура, культурные различия, межкультурная коммуникация, символы как невербальное средство межкультурных коммуникаций, культуры зоны Причерноморья, Евразийский экономический союз.

Yulia P. Ten - Ph.D. of philosophy, professor. Rostov branch of Russian customs academy. Rostov-on-Don, Russian Federation

Тен Юлия Павловна - доктор фрилософрских наук, професссор кафредры управления и экономики таможенного дела. Ростовский фрилиал Российской таможенной академии. Ростов-на-Дону, Россия.

The Russian Federation is one of the countries belonging to the cultural zone of the Black Sea countries. A variety of tribes and peoples (Cimmerians, Scythians, Sarmatians, Greeks, Romans, Slavs, Alans, Meots, Khazars, etc.) lived there on the territory of the Russian Black sea region, more than two thousand years ago. In the modern period, here live representatives of various peoples - Russians, Ukrainians, Greeks, Tatars, numerous peoples of the North Caucasus and Transcaucasia, etc. Therefore, traditionally, this regional zone of Russia is a meeting place for different cultures, religions and civilizations. In modern times it is a zone of contact between Christian (Orthodox), Islamic and Buddhist civilizations. The formation of the Customs and Economic Union within the framework of 
the five post-Soviet countries (Russia, Belarus, Kazakhstan, Kyrgyzstan and Armenia) promotes closer and closer cultural contacts between these countries, not only in trade, economical, but also in socio-cultural relations $[15,17]$.

The development of any culture is impossible without the international interaction of different peoples. The phenomenon of intercultural communication is born at the moment when the subjects perceive the interaction of cultural differences from each other. Cultural differences are the universal requisite of the communicative process, and these differences should be considered as a permanent component of a unique mode of communication. Differences signal the need for adaptation [3, p.100]. Intercultural communication is "communication that occurs in a situation of cultural differences awareness that manifest themselves in language, values, customs and habits" [12, 390]. Intercultural communication is "a communicative phenomenon in which participants with an excellent cultural background come into direct or indirect contact with each other" [7, p.16]. The emergence of cultural differences between peoples is conditioned by combination of such factors of the ethnic community development as: the realities of political history, the features of the natural and climatic landscape, the economic and everyday traditions of organizing life activity, the peculiarity of ethnic psychology, religious views, aesthetic tastes.

If a person of one culture believes that a representative of another culture thinks, perceives and evaluates things as he does, then he has no knowledge of cultural differences. The English expression "What can we know of England who only England know?" Indicates that we cannot know ourselves and our own culture without the knowledge of other people, other cultures: we need at least one contrasting example for comparison. Differences do not exist on their own: only contact with others, comparing one's own with another's, imparts to one or another cultural element the status of a differential feature. The signs, performing a differentiating function with respect to other local cultures, are appeared to be integrating for a given community.

"There is no absolute truth, there is no universally valid or invalid way of perception or thinking ... each culture has a unique logic, a special system of rules," - as T. Saral considers [11, p.393]. Hence, there is a need for awareness of cultural differences and the need for us to understand the specifics of other socio-cultural systems.

Cultures vary on the basis of "deep culture", under which M. Jardian understands the system of values, worldview and ways of social organization of a community. Deep culture is the basis of a "surface culture", which manifests itself in clothing, culinary preferences, architecture peculiarities, etc. [4, p. 59] In this regard, it is interesting to note that at the level of "surface culture" all social communities of the Black sea area in the territory of the Russian Federation share a system of national symbols, norms, values, traditions and patterns. At the level of "deep culture", these social (ethnic) communities adhere to the beliefs, customs, traditions and norms of their traditional religions and cultures.

Differences between cultures lead to certain difficulties in communication. "Cultural differences between communication participants function as boundaries or barriers that need to be overcome. In this case, understanding and satisfaction will be achieved" [4, p.102]. Differences do not exist on their own: only contact with others, comparing one's own with another's, imparts to one or another cultural element the status of a differential feature. The signs performing a differentiating function with respect to other local cultures are considered to be integrating for a given community. In order to identify ethnodifferentiating signs, it is necessary to interact at least two cultures. The characteristics, characterizing this or that local culture break up into three groups: common for all mankind, general, nonspecific; specific for a group of local cultures - relatively specific; specific only for a given local culture - absolutely specific. It is interesting to note that in modern international management transnational corporations widely use the strategy of adaptation in the development of marketing strategy of penetration to foreign markets, taking into account the 
ethno-cultural identification of consumers in the context of marketing communications [17, p. 32-37].

Communication between communicators with a similar cultural basis has broader prospects for mutual understanding than communication between communicators with different cultural bases. Since ancient times, between Belarusians, Ukrainians and Russians there are strong ethno-clan, language, religious, economic and other ties. These peoples, by virtue of common features in culture, can more easily find a common language of mutual understanding than for instance with representatives of Chinese or Bengali cultures. Representatives of close cultures have less cultural distance. Thus, most Ukrainians, Belarusians and Russians are Christians. So, the Orthodox branch of Christianity is held by the Georgians. The Armenian Apostolic Church is close to the Russian Orthodox Church. Therefore, traditionally, marriages between representatives of one branch of Christianity are very common.

When differences between peoples within their activities in different countries increase, the number of potential participants in intercultural communication decreases. Causes of increasing cultural differences may be political, religious, legal and others. For example, in the post-Soviet period, when all fifteen republics of the USSR became independent countries, there was a tendency to increase intercultural differences between the representatives of these countries. For example, Latvia, Lithuania and Estonia became members of the European Union, which resulted in a decrease in the degree of international contacts between Russia and the Baltic countries. Moreover, these countries have introduced a law, prohibiting the use of Soviet symbols, which is inapplicable to the selfawareness of most Russians. On the contrary, Eurasian economical union was created in the post-Soviet period. At present, it includes the Russian Federation, the Republic of Belarus, the Republic of Kazakhstan, the Republic of Kyrgyzstan and the Republic of Armenia. The creation of a single Economic Zone and the Customs Union of these five countries contributes to the expansion of opportunities for mutual trade, the exchange of capital, labor forces. Therefore, at present, the vector of the civilizational development of the countries of the former USSR leads to a closer intercultural interaction between Russia, Belarus, Kazakhstan, Kyrgyzstan and Armenia [15, p.111-112].

The degree of similarity (difference) of the compared cultures can be different. Polar in this comparison will be: very close cultures - a maximum of similarity and a minimum of differences; very distant cultures - a minimum of similarity and a maximum of differences [2, p.2]. Certainly, the degree of cultural differences between the culture of ancient Greek cities-policies on the modern territory of Russia in a high degree differs from the culture of modern cities of the Russian Black Sea Region.

Cultural differences are based on religious differences. So, Azerbaijanis traditionally profess Islam, which lays a mark on their way of life and culture. Georgians profess Orthodoxy. Buddhism is the most widespread religion among the Kalmyks. Bulgarians profess Orthodoxy. However, in order to achieve a high degree of productivity in terms of a positive dialogue, representatives of all peoples adhere to norms and standards of international etiquette and ethics of communication.

Signs of intercultural differences can be interpreted as differences between verbal and non-verbal codes. The process of understanding an alien culture is a cognition of deciphering of "other" codes, converting them into their own". In other words, intercultural communication is carried out through verbal means, that is, language. For example, the Russian language is the universal verbal means of international communication on the territory of all constituent entities of the Russian Federation. However, it should be noted that in each of the Republics of the Russian Federation there is a list of official languages of the Republic. For example, Russian and Ossetian languages are the official languages of 
the Republic of North Ossetia-Alania. Russian is a compulsory language for studying in all educational institutions of Russia.

However, "it is very important to avoid the postulate that in all situations it is necessary to rely on language. Communication requires both linguistic knowledge and nonlinguistic knowledge" [4, p. 226]. As D. Moraine writes: "Reading and communication in a foreign language does not guarantee the achievement of mutual understanding. The decisive factor in understanding is that there are cultural aspects beyond lexical: aspects that include many elements of non-verbal communication" [8, p.64]. Hence the need not only to teach a foreign language, but the ability to "enter" into the world of another people, its psychology, traditions, religious ideas, etc.. "There is a big difference between the way that individuals communicate information to each other, using ordinary speech and written words, and the way we communicate with each other using coded conditional forms of nonverbal behavior and non-verbal signs and symbols," believes E. Leach [14, p. 14]. Therefore, non-verbal means play an important role in intercultural communication.

Thus, intercultural communication is an important part of intercultural interaction, during which the process of transmission and exchange of messages is carried out (between cultural subjects through special sign means (natural and artificial languages). A message is a text that can be read by a representative of another culture only on the basis of adequate knowledge of the sign-symbolic content of this text.

Appeal to the non-verbal method of intercultural communication is realized if the cultural differences of the participants are so great that they serve as a sufficient obstacle for using the verbal method. Non-verbal means of intercultural communication are things, phenomena and processes, whose sign-symbolic meaning can be comprehended by the subject of intercultural communication without involving the verbal language and translated into the ideological-figurative language of one's own culture. When studying non-verbal components, it is necessary to take into account the socio-stratification, religious, cultural, political and legal foundations of their functioning in a particular society. For example, such a nonverbal reception as a nod can be interpreted and evaluated in various ways depending on the sociocultural situation (religious, socio-status, emotional-expressive, etc.).

K. Sitaram and R. Cogdell define non-verbal language as "a system of symbols, signs and gestures, containing certain reports with a high degree of accuracy, which is used and developed for communication purposes by members of a given culture" [10, p.131]. A person studies nonverbal symbols from four main sources:

1) from their own culture through interpersonal communication, observing members of their community;

2) through television, cinema, periodicals;

3) developing their own idiosyncratic methods;

4 ) as a result of interaction with representatives of other cultures.

In the scientific literature, there are different criteria for classifying the means of nonverbal communication. V.V. Kochetkov distinguishes the following non-verbal means of communication: physiognomic mask, clothing, constitutional peculiarities, objects exchange, gestures, postures, distances between companions, mutual position of interlocutors, facial expression, acoustic (speech-related) non-verbal means of communication, acoustic (not related to speech) non-verbal means of communication, tactile non-verbal means of communication, smell, skin reactions [13, p.188]

Each of the intercultural communication participants as the bearer of a particular culture is programmed to perceive things in a certain way, to evaluate them, to behave in terms of given representations, norms and traditions. Individuals interpret messages in terms of their knowledge, due to a particular context or situation. The basic condition for the intercultural understanding implementation is the ability of the interaction subjects to adequately interpret the symbols. The cultural differences in different peoples perception 
act as the significant barrier in the understanding and evaluation of the same objects, phenomena and processes. To the extent that the communicator and the recipient possess a common socio-cultural experience, they approximately equally interpret the meanings of the symbols, which promotes mutual understanding between them. However, the significances and meanings of symbols in different cultures may be different. For instance, the ancient Greeks have a rose as a symbol of beauty, happiness, fertility. In ancient Rome, the rose is the embodiment of luxury and effulgence, as well as a symbol of triumph. In early Christianity the thorns of the rose denoted pain, blood and martyrdom, and also expressed the idea of the inevitable punishment for human sins. In Orthodoxy, the rose did not take root, giving way to the white lily as a symbol of the virginity of the Virgin Mary. In Western Christianity, the rose is a symbol of purity and paradise holiness, the attribute of the Virgin. A golden rose is a symbol of the Pope. In Protestantism, the rose is a sign of mystery, secret Masonic societies. In the XIX-XX centuries red rose stands as a symbol of the Socialist International. Thus, the results of intercultural communication can range from complete coincidence to a significant disagreement among subjects in the symbols interpretation.

Different cultures have diverse value systems. Cultural differences, apparently, make intercultural communication almost impossible for an uneducated, ignorant person. Individuals who seek to communicate effectively, ask how they can communicate with representatives of other cultures? "If a person wants to communicate with another culture, then he should develop a new look at interpersonal communicative behavior" [10, p.5]. What does this mean? According to $\mathrm{E}$. Hall, in the course of intercultural communication, "a person must go on a difficult journey beyond his culture that entails the most significant feat of all is gradually the liberation from the clutches of an unconscious connection with his culture" [6, p.1]. B. Ruben writes: "In the process of human communication, our symbols and the concrete values assigned to them become generally shared and standardized, intersubjective. Constantly using our symbols and meanings, we as if "attach" to them, objectify them, and in fact, make them part of the environment to which we must adapt" [9, p.88]. The theory of acculturation and the development of cultural identity by J. Kim and W. Goodikunst is the most productive for understanding the intercultural communication essence. In this theory, intercultural communication appears as a mutual symbolic process, involving the exchange of meanings between representatives of different cultures. Culture - the realm of life patterns, the universe of information, which develops cultural-pattern models of perception and understanding of the world. "Culture is imprinted in every individual as a model of perception, attitudes and behavior that is accepted and expected by other members of the given society" [7, p. 48]. The inseparable relationship between cultural models and the individual internal state is coordinated in the individual through the concept of cultural identity. Inculturation is the process of adapting individuals to the surrounding cultural values during all stages of socialization. Kim pays special attention to the dynamics of human adaptation to a foreign culture, described by means of the concept of "stress-adaptive growth dynamics". For successful adaptation, several conditions are necessary (communication with the new environment, knowledge of a foreign language, positive motivation, access to the media, participation in various cultural events). The phenomenon of acculturation is defined as adaptation (behavior code changes) under the influence of hostile conditions with the subsequent development of intercultural identity by integrating into a new environment. The result of this process is the formation of "intercultural identity" - the psychological state of a stranger, which distinguishes them from representatives of a new cultural environment. In the scientific literature, such concepts as "multicultural person" (Adler), "marginal" (Lum), "universal man" (Tagore, Walsh), "cultural hybrid" (Park) are synonymous with "intercultural identity". 
If intercultural communication appears as the exchange of symbols between cultures, the most important result is the acceptance by the recipient culture of the symbols of a communicator culture (or donor culture). Herewith the discrepancies in the interpretation of a particular symbol will be insignificant in cultures with a minimum coefficient of cultural differences. However, the discrepancies in the interpretation of the symbol may be higher in the cultures where the coefficient of cultural differences is rather high. It should be noted that each symbol is potentially open to new interpretations in its historical and cultural development.

Thus, it easier to find common points of contact in disclosing the meanings of symbols for the individuals, involved in the process of intercultural communication within a single civilizational space. In the context of intercultural communication with representatives of other types of civilizations, the method of interpreting "alien" symbols is used to convey cultural meanings by analogy with "our own", which is an attempt to reveal those meanings of a symbol that can be identified in the ideological-conceptual and sensually- imaginative relations with the meanings of a symbol from another culture. How does a person from another culture understand the symbol, if this symbol is absent in his native culture? The solution of this problem can be illustrated by the following example, cited by D. Jiles and T. Middleton. Try to explain who "Father Christmas" is, to a representative of another culture, where this fairy-tale figure does not exist. "In order to understand "Father Christmas", it is necessary to create a concept and a way by which to express it. If we belong to a culture in which there is no "Father Frost", then we should try to connect this concept with a similar concept from our own culture in order to identify it as "similar or different from ..." [5, p.62]. There is an image of Father Frost in Russian folklore. He is very similar in image and in a number of his functions with Santa Claus. We learn the image of Father Frost by analogy with Santa Claus, because in this case we share similar symbolic codes.

Finally, we formulate the most important conclusions. A symbol is a universal means of culture that in a sensually perceivable form encodes ideas, ideals and spiritual values that are fundamental for the functioning of society and culture, preserving and transmitting them in intra- and intercultural communication processes. The symbol is a way of realization of intercultural communication between different subjects both in the historical and cultural and spatial dimensions.

One of the main components of intercultural communication is the process of symbol exchange between cultures. The problem of awareness of cultural differences by subjects of intercultural communication lies in their ability to adequately interpret the symbols of a "foreign" culture in an adapted form. If the subjects of intercultural communication with the least degree of cultural differences, discrepancies in the interpretation of the symbol will be insignificant, then in subjects with a high degree of cultural differences, the discrepancies in the interpretation of the symbol are more significant. In the latter case, for the transmission of cultural values by means of symbols, a way of interpreting "alien" symbols is used, by analogy with "our own", which is an attempt to reveal those meanings of a symbol that can be identified in the ideological-conceptual and sensory-imaginative relationships with the meanings of the symbol from other cultures [16, p.103]. An important result of intercultural communication is the acceptance of recipient culture by symbols of a donor culture. Symbol, penetrating from one culture to another, takes root in the latter and becomes open to interpretation. Thus, the symbolic system of the Eurasian Economic Union is being formed in the modern period. It is interesting that it is the prerevolutionary Russian culture and Soviet culture that act as donor cultures for the search for symbols that could be universally valid for the formation of intercultural identity of the member states of the EAEU. 


\section{Лumepamypa}

1. Casmir F.L. A multicultural perspective of human communication // Intercultural and international communication. N.-Y., 1978.

2. Dodd C.H. Perspectives on cross-cultural communication. Kendall, 1977.

3. Ellingsworth H.W. Conseptualezing intercultural communication // Communication yearbook I / Ed. by B.D. Ruben. New Jersey, 1977.

4. Guardian M. Communicating across cultures. L., 1999.

5. Giles J., Middleton T. Studying culture: a practical introduction. Malden, 1999.

6. Hall E. T. Beyond culture. N.-Y., 1976.

7. Methods for intercultural communication research /Ed. by W.B. Gydukunst, Y.Y. Kim. N.-Y., 1984.

8. Morain G.C. Kinesies and cross-cultural understanding // Culture bound. Bridging the cultural gap in language teaching / Ed. by J. M. Valdes. Cambridge, 1994.

9. Ruben B.D. Communication and human behavior. N.-Y., 1984.

10. Stewart E.C. Outline of intercultural communication // Intercultural and international communication / Ed. by F. L. Casmir. N.-Y., 1978.

11. Saral T.B. Intercultural communication theory and research: an overview // Communication yearbook I / Ed. by B.D. Ruben. New Jersey, 1977.

12. Sitaram K.S., Cogdell R.T. Foundations of intercultural communication. Columbus, 1976.

13. Кочетков В.В. Психология межкультурных различий. М., 2002.

14. Лич Э. Культура и коммуникация: логика взаимосвязи символов. М., 2001.

15. Тен Ю.П. The shaping of a symbolic model of the Eurasian economic union as basis for marketing strategy // Гуманитарные и социально-экономические науки. 2017. № 3.

16. Тен Ю.П. Роль символов в международных маркетинговых коммуникациях // Академический вестник Ростовского филиала Российской таможенной академии. №3 (20). 2015.

17.Тен Ю.П. Камалов А.В. Значение и роль этно-культурной идентификации на поседение потребителей в контексте маркетинговых коммуникаций // Гуманитарные и социальные науки. 2015. № 3.

\section{References}

1. Casmir F.L. A multicultural perspective of human communication // Intercultural and international communication. N.-Y., 1978.

2. Dodd C.H. Perspectives on cross-cultural communication. Kendall, 1977.

3. Ellingsworth H.W. Conseptualezing intercultural communication // Communication yearbook I / Ed. by B.D. Ruben. New Jersey, 1977.

4. Guardian M. Communicating across cultures. L., 1999.

5. Giles J., Middleton T. Studying culture: a practical introduction. Malden, 1999.

6. Hall E. T. Beyond culture. N.-Y., 1976.

7. Methods for intercultural communication research /Ed. by W.B. Gydukunst, Y.Y. Kim. N.-Y., 1984.

8. Morain G.C. Kinesies and cross-cultural understanding // Culture bound. Bridging the cultural gap in language teaching / Ed. by J. M. Valdes. Cambridge, 1994.

9. Ruben B.D. Communication and human behavior. N.-Y., 1984.

10. Stewart E.C. Outline of intercultural communication // Intercultural and international communication / Ed. by F. L. Casmir. N.-Y., 1978. 
11. Saral T.B. Intercultural communication theory and research: an overview // Communication yearbook I / Ed. by B.D. Ruben. New Jersey, 1977.

12. Sitaram K.S., Cogdell R.T. Foundations of intercultural communication. Columbus, 1976.

13. Kochetkov V.V. Psychology of intercultural differences. M., 2002.

14. Lich E. Culture and communication: the logic symbols relationship. M., 2001.

15. Ten Yu.P. The shaping of a symbolic model of the Eurasian economic union as basis for marketing strategy // The Humanities and socio-economic sciences. 2017. No 3.

16. Ten Yu.P. The role of symbols in international marketing communications // Academic Bulletin of the Rostov Branch of the Russian Customs Academy. No 3 (20). 2015.

17. Ten Yu.P. Kamalov A.V. Importance and role of ethno-cultural identification for visiting consumers in the context of marketing communications // The Humanities and socio-economic sciences. 2015. No 3. 